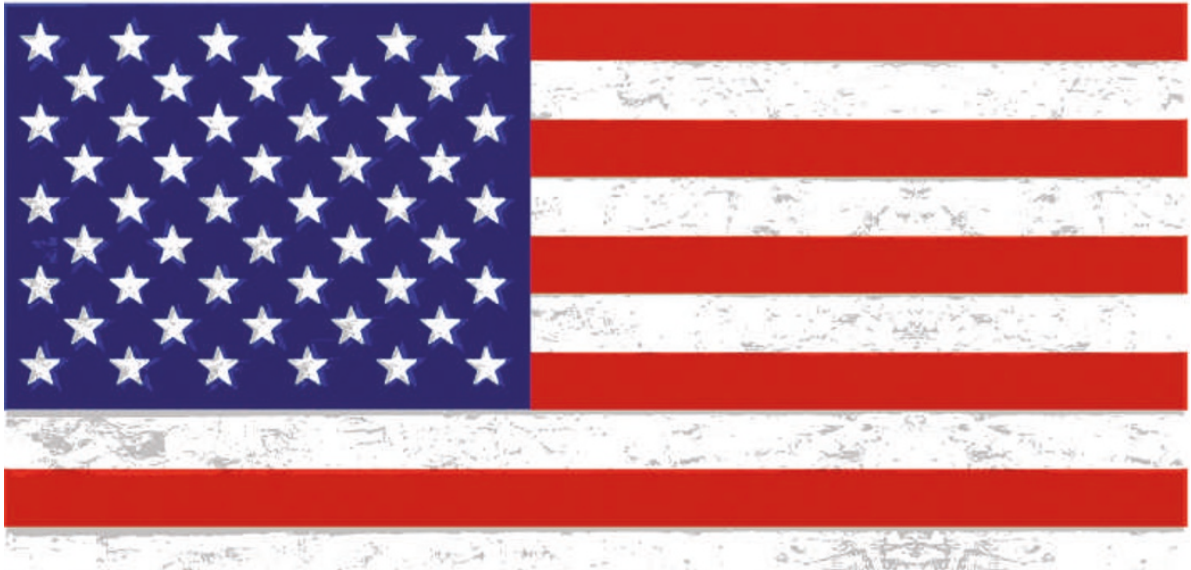

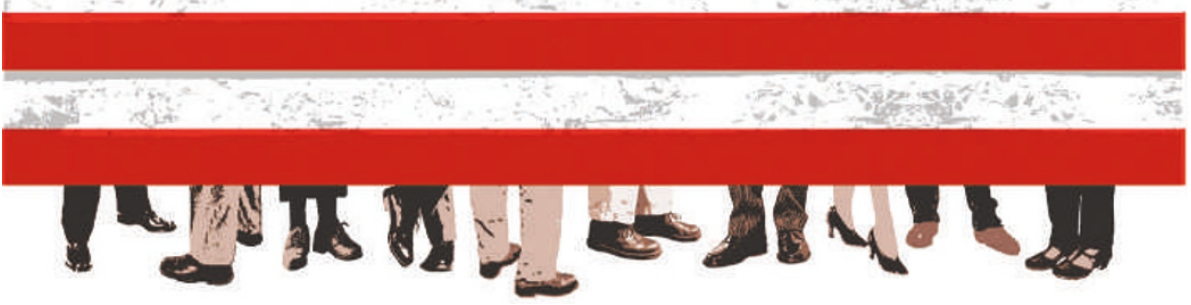

\title{
Science's secret service
}

\section{The Jasons: The Secret History of Science's Postwar Elite \\ by Ann Finkbeiner \\ Viking: 2006.304 pp. $\$ 27.95$}

\section{Daniel S. Greenberg}

Advice from science to politics runs along diverse paths. Einstein wrote to US President Franklin D. Roosevelt to warn of the possibility of nuclear explosives. C. P. Snow asserted that the physicist Frederick Lindemann's close friendship with Churchill gave him "more direct power than any scientist in history". In response to Sputnik, President Eisenhower established a committee of scientists to advise the White House. And nuclear physicist Edward Teller exalted the Star Wars defence programme to a receptive President Reagan. Renown, personal relationships and committees have all linked science to government in the modern era.

And then there is the group known as Jason, which is unlike any of them. Working exclusively for the US government, to which it is financially tethered, Jason consists mainly of science professors - mostly self-selected and working in secret - who devote a large of part of each summer to intense, collaborative studies of worrisome scientific and technological issues confronting the government. The title Jason apparently has a playful origin, being derived from the myth of the Argonauts.

Since Jason was founded in 1960, about 100 scientists have been taken into its ranks, of whom 30 to 60 are active at any one time. Physicists predominated in the early days, as befitted the reigning scientists of the Cold War, but life scientists and others have been included since. At the latest tally, 11 have been Nobel laureates and 43 were members of the US National Academy of Sciences. Among them are some of the great names of science: Freeman Dyson, Richard Garwin, Charles Townes, Marvin Goldberger and John Wheeler. Most of Jason's studies concern military matters, and about half to three-quarters of its reports are classified; the exact proportion is unknown, because Jason, although not itself a secret, generally shuns publicity.

The public record contains little mention of Jason, with just a few published accounts, largely suspicious of the secretive proceedings of superstar professors temporarily employed by the Pentagon on unknown projects. But the veil is partly lifted by Ann Finkbeiner, who teaches science writing at Johns Hopkins University; her book The Jasons is based on interviews with 36 of the group's members.

Finkbeiner describes her book as "less a respectable history than a series of stories in more or less chronological order". She tells of Jason's proposal to dampen the fury of the Vietnam War by building a high-tech barrier of sensors and mines, backed by artillery and aircraft, to throttle the passage of North Vietnamese troops and supplies along the Ho Chi Minh trail. Embraced by the beleaguered defence secretary, Robert McNamara, the barrier lacked an important ingredient: support from the military, which was distressed by its costs and echoes of Maginot Line immobility. Although a stretch of the barrier was built, a Pentagon official retrospectively labelled it "horribly naive". The episode was not fruitless, however, according to several Jasons, who claimed the barrier as the prototype for the electronic battlefield

Involvement in the Vietnam War, even if aimed at lessening its destructiveness, brought self-doubt and opprobrium to the Jasons. Student activists denounced and harassed them after stolen records were depicted as implicating Jason deeply in the conduct of the war. A 1967 Jason study, "Tactical Weapons in Southeast Asia", demonstrated the futility of nuclear weaponry in the Vietnam War but remained classified for about 20 years. "Jason became the devil," a Pentagon official remarked. "No matter that some of them had excellent doveish credentials, they were Jason."

The Jasons is particularly valuable in its illumination of the realpolitik of scientific advice. Claire Max, one of the few women Jasons, remarks: "I get morally indignant about something that the government is doing that doesn't make technical sense, and I suggest to the rest of my colleagues at Jason that we do a summer study. And they tactfully point out that there's no point in doing it if nobody's going to listen."

Sidney Drell warns not to expect too much when providing scientific advice to government. "The ratio of output to input in doing government work is never high," he observes. "I take great comfort in the fact that for fiftyseven years we've managed severe crises and not used nuclear weapons. I just want to see that we keep our wits about us. And I haven't lost my optimism."

Among these stars of the scientific establishment, attitudes vary about going public with the weighty issues of their government work. Richard Garwin, the quintessential insider, is legendary for speaking out publicly on topics ranging from the environmental impact of supersonic flight to the control of nuclear arms. Some half-a-dozen current or past Jasons are prominent in the leadership of the Federation of American Scientists, which pioneered scientific activism over arms control and international collaboration. In contrast, Jason member Rich Muller argues: "Once you come out publicly for something, you're basically taking sides, and your value as an adviser is decreased."

Throughout its nearly 50-year history, Jason's free-wheeling style has often grated on the defence officials who pay its bills. Clashes have ensued, and Jason has had its ties to the Pentagon rearranged and its client base expanded to other government agencies. With its intolerance of dissent, the George W. Bush administration has been especially trying for Jason, particularly on the sensitive issue of who is appointed. However, Jason goes on, although its traditional cohesiveness is challenged by the growing interdisciplinarity of science, and family and work patterns that make it difficult for members to get away for six weeks in the summer.

Elite academic scientists working on secret government projects would seem to be the 
basis for a great story. But The Jasons rings few dramatic bells. And the author observes: "Jasons think they've done the country good, but they haven't got much clear evidence."

Perhaps a more sceptical attitude towards the Jasons in particular and the advisory process in general would have paid off. My own observation is that politicians seek scientific advice to support their preconceptions, not to steer them to wisdom. But where secrecy previously obscured public view of the Jasons, reverence is the problem here. Stockholm

\section{A journey to remember}

\section{In Search of Memory: The Emergence of a New Science of Mind \\ by Eric R. Kandel \\ W. W. Norton: 2006.510 pp. \$29.95}

\section{Yadin Dudai}

Few can interlace their autobiography with the evolution of a scientific paradigm. Even fewer can weave such a story seamlessly. Eric Kandel is one of these. His career, from his training in Harry Grundfest's laboratory at Columbia University in New York more than fifty years ago to a remarkably productive present, also at Columbia, epitomizes his ardent reductionist approach to the neural sciences. Its formal pinnacle was the Nobel Prize in Physiology or Medicine, which Kandel shared in 2000 with Arvid Carlsson and Paul Greengard for their discoveries concerning signal transduction in the nervous system.

Kandel's intellectual journey in neuroscience can be traced back to his first encounter with Grundfest. The enthusiastic medical student, with a strong background in history and literature, proposes unveiling the brain substrates of Freud's three psychic structures, the ego, superego and id, in six months. Grundfest, the seasoned professor of neurology, suggests a different agenda, no less grandiose: to understand the mind, he replies, we need to look at the brain one cell at a time. The narrative of the brain sciences in the past century is made up of attempts to negotiate between these two extremes. In his admirable personal version of this narrative, Kandel is still a grundfestian, but appreciates that the bottom-up approach still has a long way to go.

Nowhere, perhaps, is this conflict between reductionism and global approaches to the brain more evident than in memory research. Memory is a term applied nowadays to a wide gamut of functions, ranging from experiencedependent modification of reflexes in brainless organisms to the recollection of personal syndrome is not confined to hostages who become enamoured of their captors: it can also afflict observers who fall for their subjects. As Finkbeiner wrote of an anonymous Jason identified only as "Dr. Y": "She might look plain if she didn't move so gracefully, and intense and honest to the bone."

Daniel S. Greenberg is a journalist in

Washington. His new book, Science for Sale, will be published next year by the University of Chicago Press. and if she didn't sit so quietly, self-possessed

events in their investigators. Even if such an inclusive definition is accepted, the distinction should still be made between memory as a process and as an item with mental content.

The process is assumed to be subserved by the plasticity of synapses, the functional contacts between nerve cells. One could further assume that the basic building blocks of the plasticity machinery were conserved in evolution. If this is the case, why not approach memory by studying its simplest forms in the simplest of organisms? This philosophy has guided Kandel and given the timid sea-slug Aplysia a prominent position in textbooks of neuroscience. The approach, anchored in the achievements of molecular biology, has proved highly productive in identifying plasticity mechanisms that subserve memory. What it doesn't address satisfactorily is the content and meaning of memory items. This requires an understanding of how brains encode specific pieces of mental information. Many would argue that this calls for the spatiotemporal codes of neuronal populations to be deciphered. Further- more, given the immense difference in complexity and the likelihood of emergent properties, it is unlikely that probing the ganglia of Aplysia can tell us how our brain recalls our first love or our father's face.

Nevertheless, the reductionist approach to behavioural plasticity, of which Kandel's work is the prime example, is a success story that has given us models of molecular and cellular plasticity that propose how experience affects nerve cells. It is now for those who follow Kandel to link the molecular and cellular level with the systems level of analysis. This integration is the major challenge facing the science of memory, and might require, in addition to new methodologies, a change of zeitgeist or an amalgamation of approaches.

Kandel's book is enthusiastically recommended as a captivating account of the career of a prominent leader in contemporary neuroscience. The author is not only an authoritative scholar but also a marvellous popularizer and narrator, who brings to the story an attractive mix of facts, personal touches and wisdom, seasoned with reflective humour. But In Search of Memory is not just about science: it is also about history and identity. Kandel is a devoted scientist, humanist, family man and proud Jew. He follows, by his own definition, the "Talmudic tradition writ large. But rather than annotate a religious text, we annotate texts written by evolutionary processes working over hundreds of millions of years."

Kandel was just a child when he emigrated from Austria to the United States, but the Holocaust and the trauma of European Jewry are deeply embedded in his memory. His contempt for racism is clear. In the background hovers the terrible awareness that many of his generation perished, unknown, in concentration camps before they had a chance to explore and contribute to the world. When the Austrian president contacts Kandel and expresses his desire to honour the new Nobel laureate of Viennese origin, Kandel's reaction is to organize a symposium in

Vienna to acknowledge Austria's central role in the Nazi atrocities and evaluate the significance for scholarship of the disappearance of the Jewish community in Vienna. Kandel's accounts of incidents during this visit to Vienna should be read carefully by those who ignore lingering undercurrents of anti-Semitism.

The Greek poet Constantine Cavafy, in his poem Ithaka, which recounts the return of Odysseus to his homeland, advises his hero not to hasten:

As you set out for Ithaka,

Hope the voyage is long,

Full of adventure, full of discovery...

Better if it lasts for years...

Ithaka gave you the marvellous

Without her you would not have journey sailed away. 